SOCIAL WORK VALUES AND ETHICS 
FREDERIC G. REAMER, SERIES EDITOR

Social work has a unique history, purpose, perspective, and method. The primary purpose of this series is to articulate these distinct qualities and to define and explore the ideas, concepts, and skills that together constitute social work's intellectual foundations and boundaries and its emerging issues and concerns.

To accomplish this goal, the series will publish a cohesive collection of books that address both the core knowledge of the profession and its newly emerging topics. The core is defined by the evolving consensus, as primarily reflected in the Council of Social Work Education's Curriculum Policy Statement, concerning what courses accredited social work education programs must include in their curricula. The series will be characterized by an emphasis on the widely embraced ecological perspective; attention to issues concerning direct and indirect practice; and emphasis on cultural diversity and multiculturalism, social justice, oppression, populations at risk, and social work values and ethics. The series will have a dual focus on practice traditions and emerging issues and concepts.

The complete series list follows the index. 


\section{SOCIAL WORK VALUES AND ETHICS}

FIFTH EDITION

Frederic G. Reamer 


\section{COLUMBIA UNIVERSITY PRESS}

\section{Publishers Since 1893}

New York Chichester, West Sussex

cup.columbia.edu

Copyright (C) 2018 Columbia University Press

All rights reserved

Library of Congress Cataloging-in-Publication Data

Names: Reamer, Frederic G., 1953- author.

Title: Social work values and ethics / Frederic G. Reamer.

Description: Fifth Edition. | New York : Columbia University Press, [2018] |

Revised edition of the author's Social work values and ethics, c2013. |

Includes bibliographical references and index.

Identifiers: LCCN 2018015872 | ISBN 9780231188289 (hardback : alk. paper) |

ISBN 9780231188296 (trade pbk. : alk. paper) | ISBN 9780231547758 (e-book)

Subjects: LCSH: Social service-Moral and ethical aspects. | Social workers-

Professional ethics. | Social service-United States.

Classification: LCC HV10.5 . R427 2018 | DDC $361.3 / 2-\mathrm{dc}_{23}$ LC record available at https://lccn.loc.gov/2018015872

Columbia University Press books are printed on permanent and durable acid-free paper. Printed in the United States of America 